\title{
Survey the Effective Political Factors on Nationalism Consumption Development
}

\author{
Kumars Ahmadi ${ }^{\mathrm{a}}$, Mahdia Rezaee ${ }^{\mathrm{b}}$ \\ ${ }^{1}$ Department of Business Management, Islamic Azad University, \\ Sanandaj Branch, Sanandaj, Iran \\ a,bE-mail address: ahmadi1218@yahoo.com , mahdierze@gmail.com
}

\begin{abstract}
The current article is done with the aim of determining the effect of political factors level on nationalism consumption of Sanandaj county consumers in 133. The method of this article is exploratory - measurement. The objective society, consist of Sanandaj Islamic Azad and governmental university experts in the field of marketing that is a kind of limited society and all society members. The information collection tool includes a substantiative questionnaire with the Likret spectrum. For analyzing data, the SPSS statistic software and for surveying the level of criterion and precaution effective variables, the Nonparametric Binomial test was used. The analysis results showed that the effective political indexes on nationalism consumption development includes: the boycott position, the animus of governmental undertakers, revision in fiscal rules, the aperture level of country borders, the economic handicap of government in the political conferences and the prophecy of cultural system and media, that all these six indexes (factors) have an effect on nationalism consumption.
\end{abstract}

Keywords: Political Factors; Nationalism Consumption

\section{INTRODUCTION}

Nowadays in the universalization era, one of the considered subjects is "Nationalism" in the economic, commercial and political cliques and seems that Iranian people have a nationalism tendencies and these, is caused a "Nationalism Consumption" and it can be considered as an advantage for internal productions against foreign productions (Heydarzade and Zandhesami, 2009). But nevertheless of persuasion to consume the internal production and the support of internal productions in different ways like limited the entrance of foreign productions and propound the subjects like national production (for example national auto car), a lot of tendency in foreign productions even in smuggling way is seen (Heydarzade and Zandhesami, 2009). The nationalism consumption is consumers' belief in predominance of internal country or region goods (productions), although it hasn't any logical fundamental, and this is a conception that is widely used for surveying and forecasting of consumers behavior against the foreign goods. The nationalistic consumers believe that a foreign goods shopping is wrong and this (Shopping) has a negative effect on national economic and lead to a decrement in job opportunity and it's against the patriotism feeling. Also the economic growth 
and development of any country is depending on the self-production and consumption increment. According to this, the consumption market of a country has an effective role in production development of that country, so based on this, the knowledge of internal goods consumption tendency level and its multiplier factors can be so effective for internal corporations in the competition with international factories so that they can use this tendency as an advantage in the Iran market place, and also the government can decide this policy to support these productions or not. Regarding to the importance of this subject and considered matters, this study aims to answer this question that how much political factors can be effective in nationalism consumption development?

\section{RESEARCH METHODOLOGY}

The current research, depend on the purpose, is practical and it's based on exploratory measurement method. Collecting information is by questionnaire tool in field form and by librarian studies. The surveyed statistic society in the study consist of Sanandaj Islamic Azad and governmental university experts in the field of marketing that is a kind of limited society and also all society members was chosen as statistic objects.

\section{1. Tools}

Regarding to the research subject and surveyed variables, essential information, collecting information was done by substantiative questionnaire. The measured Coronbakh Alpha coefficient for this questionnaire is 89 percent.

\section{THEORETICAL FRAMEWORK}

\section{1. Political Environment}

As Rozenblat (1994) belief, political publicity is one of the effective factors in nationalism consumption level. He said that political leader can reinforce the nationalization with showing the foreign threatens much bigger. But it's apposed that how much these factors can affect the nationalism consumption. In this field, it's useful to consider the coordinator role of "Political Freedom" and "Democracy" in the relation between political publicity and nationalism consumption. In other hands, it should be surveyed that, if other nations consumers will be effected by political publicity or the people in the country that has an absolute system. Nevertheless of the political publicities, also the political government history of countries determines the nationalism consumption level. Good, 1.k. and Huddleston, P (1995) explain the nationalism consumption level of Poland towards Russia with this logic that: the countries that were subjected by other nations abusive (like Poland) have a higher level of nationalism consumption than those countries that have history full of victory and dominance (like Russia). However the internal production distinction level may be different among these two groups of countries. So the political publicity and political history effects are two subjects that need more survey and in this field, other variables like level and the understandable power of external groups, truncation power of them and the leaders interruption level and political groups are also need to be surveyed (Haghighi and Hosseinzade, 2009). The powerful beneficiary political parties and groups may cause a change in the attitude of country in the field of commercial, consumption and other related methods (Rajaee, 2003). 


\section{2. Experimental History}

- Irena Vida (2008) in a research, surveys the role of racial association in the racialism consumers. The purpose of this article was to survey the effect of racial association on racialism and internal shopping bias. The experimental data was collected from 580 urban consumers in Bosnia and Herzegovina that was followed by racial violent contention in Balkan. The results emphasized that two factors, national identity and nationalism have a noticeable role in racial consumers. This racial association has a straight effect on both, racialism and internal shopping bias. The results prove that this two scales cause a trustworthy prediction model making of valuable racial consumption. The results also show that distinction (preference) marketing strategy may be ensured in the entrance of the multiracial markets.

- Haghighi and Hossienzade (2009) in their research as "The comparison of the internal goods (productions) consumption tendency level in Tehran with other world's regions and survey its complications in the production assessment and distinction" reaches the following results: In the current research, at first, the internal production consumption tendency level of objects consist of 400 Tehranian consumes, measured and then its rate compared with other region of the world. So regarding to this internal production consumption tendency level evaluation, an international metre, call CETSCALE is introduced, then the effect of this tendency on evaluating different level of internal and external goods, the internal productions preference and a tendency to buy an importation productions from the other countries that have a same political, economic, cultural and religious position is surveying. The primary results show that the consumers with high nationalism (in the comparison with consumers with low nationalism) have a better evaluation on internal production, but the more subtle survey shows that these consumers don't evaluate the internal productions more desirable than external productions.

\section{RESULTS AND DISCUSSION}

For surveying the question of the political factors effect on nationalism consumption development, the achieved information from the questionnaire analyzed by using the Binomial test. Table (1) shows the affect or affectless of political factors properties indexes on nationalism consumption.

As above table shows, most of 50.7 percent of responders know the first index (The boycott position against the importation to the country) as one of the most effective and important indexes on political factors. The statistic result of the binomial test also proves this at the 99 percent of certainty. So it can be asserted that: The boycott position against the importation to the country is one of the effective indexes on political factors and so nationalism consumption. Also the 70 percent of responders know the second index (The strict animus of related governmental undertakers on the support of internal productions and fight against smuggling) as one of the most effective and important indexes on political factors. 
Table1. A survey on the affect or affectless of political factors properties indexes on nationalism consumption.

\begin{tabular}{|c|c|c|c|c|c|c|c|c|c|c|c|c|c|c|}
\hline \multirow{3}{*}{ 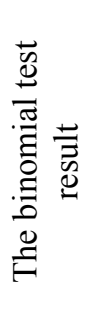 } & \multirow{3}{*}{.00} & \multirow{3}{*}{$\frac{\bar{\Xi}}{\vec{Z}}$} & \multicolumn{4}{|c|}{ Success } & \multicolumn{6}{|c|}{ Failure } & \multirow{3}{*}{ Indexes } & \multirow{3}{*}{2} \\
\hline & & & \multicolumn{2}{|c|}{ Very High } & \multicolumn{2}{|c|}{ High } & \multicolumn{2}{|c|}{ Normal } & \multicolumn{2}{|c|}{ Low } & \multicolumn{2}{|c|}{ Very Low } & & \\
\hline & & & 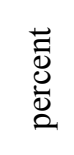 & $\begin{array}{l}\text { 岕 } \\
\text { है } \\
\text { 音 }\end{array}$ & 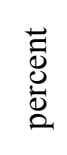 & $\begin{array}{l}\text { 怘 } \\
\text { 泀 }\end{array}$ & 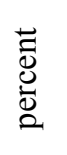 & $\begin{array}{l}\text { 岕 } \\
\text { 泀 }\end{array}$ & 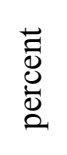 & 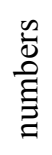 & 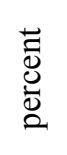 & $\begin{array}{l}\text { 岕 } \\
\text { 音 } \\
\text { la }\end{array}$ & & \\
\hline 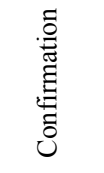 & $0 / 000$ & 12 & 50 & 6 & $41 / 7$ & 5 & $8 / 3$ & 1 & 0 & 0 & 0 & 0 & $\begin{array}{l}\text { The boycott } \\
\text { position against the } \\
\text { importation to the } \\
\text { country }\end{array}$ & 1 \\
\hline 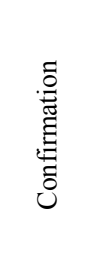 & $0 / 000$ & 10 & 30 & 3 & 70 & 7 & 0 & 0 & 0 & 0 & 0 & 0 & $\begin{array}{l}\text { The strict animus of } \\
\text { related } \\
\text { governmental } \\
\text { undertakers on the } \\
\text { support of internal } \\
\text { productions and } \\
\text { fight against } \\
\text { smuggling }\end{array}$ & 2 \\
\hline 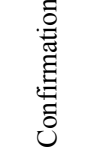 & $0 / 006$ & 11 & $45 / 5$ & 5 & $36 / 4$ & 4 & $18 / 2$ & 2 & 0 & 0 & 0 & 0 & $\begin{array}{l}\text { Revision in fiscal } \\
\text { and custom rules }\end{array}$ & 3 \\
\hline 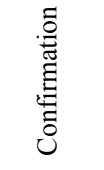 & $0 / 015$ & 12 & $41 / 7$ & 5 & $33 / 3$ & 4 & 25 & 3 & 0 & 0 & 0 & 0 & $\begin{array}{l}\text { The aperture level } \\
\text { of country borders } \\
\text { towards goods } \\
\text { smuggling }\end{array}$ & 4 \\
\hline 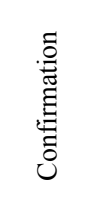 & $0 / 029$ & 11 & $18 / 2$ & 2 & $54 / 5$ & 6 & 9/1 & 1 & $18 / 2$ & 2 & 0 & 0 & $\begin{array}{l}\text { The economic } \\
\text { handicap of } \\
\text { government on } \\
\text { political } \\
\text { conferences and } \\
\text { haggling }\end{array}$ & 5 \\
\hline 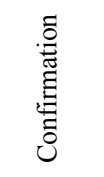 & $0 / 000$ & 12 & $58 / 3$ & 7 & $33 / 3$ & 4 & $8 / 3$ & 1 & 0 & 0 & 0 & 0 & $\begin{array}{l}\text { Iranian goods } \\
\text { consumption and } \\
\text { prophecy of } \\
\text { cultural system and } \\
\text { media }\end{array}$ & 6 \\
\hline
\end{tabular}

The statistic result of the binomial test also proves this at the 99 percent of certainty. So it can be asserted that: The strict animus of related governmental undertakers on the support of internal productions and fight against smuggling is one of the effective indexes on political factors and so nationalism. Also the $45 / 5$ percent of responders know the third index (Revision in fiscal and custom rules) as one of the most effective and important indexes on political factors. The statistic result of the binomial test also proves this at the 99 percent of certainty. So it can be asserted that: Revision in fiscal and custom rules is one of the effective indexes on political factors and so nationalism. Also the 41/7 percent of responders know the fourth index (The aperture level of country borders towards goods smuggling) as one of the 
most effective and important indexes on political factors. The statistic result of the binomial test also proves this at the 99 percent of certainty. So it can be asserted that: The aperture level of country borders towards goods smuggling is one of the effective indexes on political factors and so nationalism. The results showed that, the 54/5 percent of responders know the fifth index (The economic handicap of government on political conferences and haggling) as one of the most effective and important indexes on political factors. The statistic result of the binomial test also proves this at the 95 percent of certainty. So it can be asserted that: The economic handicap of government on political conferences and haggling is one of the effective indexes on political factors and so nationalism. Also the 58/3 percent of responders know the sixth index (Iranian goods consumption and prophecy of cultural system and media) as one of the most effective and important indexes on political factors. The statistic result of the binomial test also proves this at the 99 percent of certainty. So it can be asserted that: Iranian goods consumption and prophecy of cultural system and media is one of the effective indexes on political factors.

\section{CONCLUSION}

The current article, is done with the aim of determining the level of effective political factors on nationalism consumption development of Sanandaj County, and according to the results, the evaluated political indexes in this article: the boycott position, the animus of governmental undertakers, revision in fiscal rules, the aperture level of country borders, the economic handicap of government in the political conferences and the prophecy of cultural system and media, were all confirmed by experts and it can be asserted that the political indexes (factors) have an effect on nationalism consumption.

\section{References}

[1] Haghighi M., Hossienzade M., The comparison between the internal productions consumption tendency in Tehran with other world's regions, the Modares index of humanity science, 13(4) (2008).

[2] Heydarzade K., Zandhesami H., Evaluation the distinctions (preferences) of customers in the deciding shopping process of foreign goods, the marketing evaluation magazine. Fourth year, number 7(2009).

[3] Rajaee C., Nowadays human identity problem (playing a role in the one civilization and multi culture era), Tehran: Farhang publication (2003).

[4] Irena V., Role of ethnic affiliation in consumer ethnocentrism. Emerald Group Publishing Limited. (2008) 